\title{
A review of phosphorus nutrition in irrigated cotton farming systems of Australia
}

\author{
NACHIMUTHU Gunasekhar ${ }^{{ }^{*}}$ (D) SCHWENKE Graeme ${ }^{2}$, MERCER Clarence ${ }^{2}$, BISCHOF Callum ${ }^{3}$, HULME Pat $^{4}$ and \\ BELL Michael ${ }^{3}$
}

\begin{abstract}
Australian cotton production predominantly occurs on Vertisols. The average lint yield of cotton grown in Australia is $2260-2700 \mathrm{~kg} \cdot \mathrm{hm}^{-2}$, which is 2.5 to 3 times the world average. This high productivity per unit of land area requires efficient use of resources such as water and nutrients. However, high yields accelerate the export of nutrients such as phosphorus $(\mathrm{P})$ in seed, depleting the soil reserves of $\mathrm{P}$ more than in other countries with lower cotton yields. Recent surveys of cotton industry indicate that $P$ application rates should match seed $P$ export $\left(30 \sim 40 \mathrm{~kg} \cdot \mathrm{hm}^{-2}\right)$, but historical depletion within subsoil is still evident and is continuing. Depletion of soil $\mathrm{P}$ is typically more pronounced in the subsoil than in the topsoil $(0 \sim 20 \mathrm{~cm})$ where $P$ fertiliser is applied, as cotton roots rely on these layers as important sources of plant available water and available $\mathrm{P}$. This mismatch between zones of $\mathrm{P}$ uptake and resupply may increase stratification of available $P$ in the soil profile. Recent studies showed that cotton responded poorly to banded applications of fertiliser $\mathrm{P}$, while dispersal of fertiliser throughout the plant beds was more successful. Researchers have also observed sporadic cotton responses to applied $P$ fertiliser in soils where available $\mathrm{P}$ concentrations were well above the previously determined critical concentrations indicative of fertiliser $P$ responses in Australia. To sustain highyielding cotton production in Australia, a greater understanding of cotton root acquisition of applied $\mathrm{P}$, as well as a re-examination of critical soil $P$ concentrations for each production region are required.
\end{abstract}

Keywords: Vertisol, P stratification, Soil test critical value

\section{Introduction}

The majority of Australian cotton is grown on Vertisols (cracking clay soils), with the high crop productivity primarily as a result of the high-water holding capacity and inherently fertile nature of these soils. Recent investigations have suggested that there is a decline in phosphorus $(\mathrm{P})$ fertility of these Vertisols with years of cotton or grain production, with this decline most evident below the cultivated/topsoil layers due to the relative immobility of this nutrient in these soil types (Bell et al. 2020; Schwenke et al. 2021). In addition, Constable and Bange

\footnotetext{
*Correspondence: guna.nachimuthu@dpi.nsw.gov.au

${ }^{1}$ New South Wales Department of Primary Industries, Australian Cotton Research Institute, Narrabri, NSW 2390, Australia

Full list of author information is available at the end of the article
}

(2015) theorised that to realise the full yield potential of modern cotton cultivars $\left(5000 \mathrm{~kg} \cdot \mathrm{hm}^{-2}\right)$, the crop P uptake will need to increase from the current $P$ uptake of $30 \sim 40 \mathrm{~kg} \cdot \mathrm{hm}^{-2}$, up to $85 \mathrm{~kg} \cdot \mathrm{hm}^{-2}$. This represents major challenges for the plant physiological processes of yield establishment as well as for resource capture by the crop root system to meet growth demands. The physiological limitations to achieving these potential yields will be greatly exacerbated by the decline in native soil $P$ reserves if it is accompanied by an increasingly stratified distribution of P (Schwenke et al. 2021) in thinner and shallower proportions of the rooting zone in response to common fertiliser application practices. To overcome this limitation, it is essential to improve the understanding of soil $\mathrm{P}$ availability and cotton response to applied $\mathrm{P}$ fertiliser. In view of this, this short paper reviews the previous studies original author(s) and the source, provide a link to the Creative Commons licence, and indicate if changes were made. The images or other third party material in this article are included in the article's Creative Commons licence, unless indicated otherwise in a credit line to the material. If material is not included in the article's Creative Commons licence and your intended use is not permitted by statutory regulation or exceeds the permitted use, you will need to obtain permission directly from the copyright holder. To view a copy of this licence, visit http://creativecommons.org/licenses/by/4.0/. 
on P nutrition in Australian cotton over the past 30 years. The majority of this review focuses on irrigated cotton farming systems, however recent research on dryland cotton systems was also included in the discussion.

\section{Background}

\section{Cotton growing regions of Australia}

In Australia, cotton production is predominantly concentrated in two eastern states, New South Wales (NSW) and Queensland (QLD). The main cotton producing regions include the central highlands (including Dawson and Callide valleys, Darling Downs, St George, Dirrabandi and Mungindi valley in Queensland; and the Macintyre, Gwydir, Upper Namoi, Lower Namoi, Macquarie Valleys, Bourke, Tandou, Lachlan and Murrumbidgee/Murray valleys in NSW (Fig. 1). The emerging regions include Kununurra in Western Australia, Katherine in Northern Territory and Georgetown in northern Queensland (Fig. 1).

\section{Results and discussion}

\section{$P$ use by cotton growers over the past 10 years}

The average rate of fertiliser $\mathrm{P}$ applied by commercial cotton growers increased from $23 \mathrm{~kg} \cdot \mathrm{hm}^{-2}$ in 2000 2001 to $44.2 \mathrm{~kg} \cdot \mathrm{hm}^{-2}$ in 2019-2020 season (CRDC 2020). Average lint yields in cotton industry have been relatively stable over the last 10 years, fluctuating from 2270 to $2724 \mathrm{~kg} \cdot \mathrm{hm}^{-2}$ (The common term used by cotton industry to quantify the lint is bales. In Australia, 1 bale $=227 \mathrm{~kg}$ of ginned lint). Based on the estimates of Rochester (2007), the average seed P export for this yield of cotton would have been $23 \sim 27 \mathrm{~kg} \cdot \mathrm{hm}^{-2}$, which has generally been matched or exceeded by $P$ fertiliser addition rates over the past 10 years (Fig. 2). Data of $\mathrm{P}$ fertiliser use was not collected in the survey in some years, but the cotton consultant survey (2014-2015) revealed grower clients used a maximum of $30 \sim 40 \mathrm{~kg} \cdot \mathrm{hm}^{-2}$, with only very few clients (representing $<4000 \mathrm{ha}$. of production) using more than $40 \mathrm{~kg} \cdot \mathrm{hm}^{-2}$. The $2018-2019$ season was extremely dry, with no or very low allocation of water for irrigation, leading to one of the smallest areas planted with cotton in Australia in recent decades. Therefore, the $70 \mathrm{~kg} \cdot \mathrm{hm}^{-2}$ application rate in 2018-2019 was likely an outlier in P fertiliser use statistics of the Australian cotton industry (Fig. 2).

\section{A review of $P$ response studies and critical available $P$ concentrations for Australian cotton soils}

The inherently high fertility of cotton growing Vertisols has meant that there has not been much attention paid to fertiliser $\mathrm{P}$ response until the 1990s, when Hibberd et al. (1990) reported a response to applied P in central Queensland on a shallow basaltic dark cracking clay.
Cotton P fertiliser response experiments were conducted from 1992 to 2006 in the Macquarie Valley (Central West NSW) where the native soil P fertility is inherently lower (Schwenke et al. 2021) and the soils tested belonged to the Vertosol and Dermosol Australian Soil Classification (ASC) orders (Isbell and National Committee on Soil and Terrain 2021). Results of these trials suggested a consistent yield benefit with $\mathrm{P}$ application (Hulme 2015), and the available P in $0 \sim 30 \mathrm{~cm}$ of the soil could be depleted by just two high-yielding cotton crops. These experiments were conducted prior to the current industry recommendation to disperse the $\mathrm{P}$ fertiliser within the soil when applying fertilisers to improve plant $\mathrm{P}$ uptake. The $\mathrm{P}$ application in these experiments was done via buried-band applications, which have shown to be a relatively ineffective application strategy to ensure cotton P uptake in recent studies (Bell 2014; Griffith and Guppy 2016). Therefore, the average yield increase from $P$ application in the Hulme (2015) studies, which ranged from 1.4\% 7\% in 7 out of 8 years over 66 experiments conducted between 1992 and 2006, may be somewhat conservative. In those Macquarie Valley soils with inherently low $\mathrm{P}$ fertility, trial results indicated that a lint yield response could be expected when the soil Colwell P test (Colwell 1963) concentrations was less than $10 \mathrm{mg} \cdot \mathrm{kg}^{-1}$. The probability of yield improvement declined when Colwell $\mathrm{P}$ was between $10 \sim 20 \mathrm{mg} \cdot \mathrm{kg}^{-1}$ and there was little yield response when Colwell $\mathrm{P}$ was greater than $20 \mathrm{mg} \cdot \mathrm{kg}^{-1}$ (Fig. 3). Regionally, higher lint yield responses to applied $\mathrm{P}$ were observed in older alluvial Vertisols deposited more than 15000 years ago, compared to those deposited more recently, i.e. less than 5000 years ago.

Dorahy et al. (2004) conducted 17 fertiliser-P response field experiments (1997-2000) across four Australian cotton growing regions: upper and lower Namoi (5), Macquarie (2), Gwydir (7) and MacIntyre (3). They concluded that the critical soil Colwell $\mathrm{P}$ concentration in the cultivated layer $(0 \sim 30 \mathrm{~cm})$ for cotton yield response was $6 \mathrm{mg} \cdot \mathrm{kg}^{-1}$, somewhat lower than the $10 \mathrm{mg} \cdot \mathrm{kg}^{-1}$ found by Hulme (2015) in the Macquarie Valley studies. Where the Colwell $\mathrm{P}$ was less than $6 \mathrm{mg} \cdot \mathrm{kg}^{-1}$, Dorahy et al. (2004) recommended the application of $40 \mathrm{~kg} \cdot \mathrm{hm}^{-2}$ $\mathrm{P}$ fertiliser to build up soil $\mathrm{P}$ reserves. Where the Colwell $\mathrm{P}$ was between 6 and $12 \mathrm{mg} \cdot \mathrm{kg}^{-1}$ they recommended $20 \mathrm{~kg} \cdot \mathrm{hm}^{-2} \mathrm{P}$ to maintain soil P fertility. However, these studies also relied heavily on subsurface banded applications (narrow $2 \mathrm{~cm}$ wide bands), with $\mathrm{P}$ banded below or to the side of the planting line in 15 of the 17 on-farm trials and only dispersed through the plant bed in 2 trials. Another investigation in Western Australia (Kununurra) on a Chromic Vertisol (with Colwell P levels of $14 \mathrm{mg} \cdot \mathrm{kg}^{-1}$ at $0 \sim 30 \mathrm{~cm}$ depth) reported a cotton yield response to $\mathrm{P}$ applied in dual bands at $10 \sim 15 \mathrm{~cm}$ and 


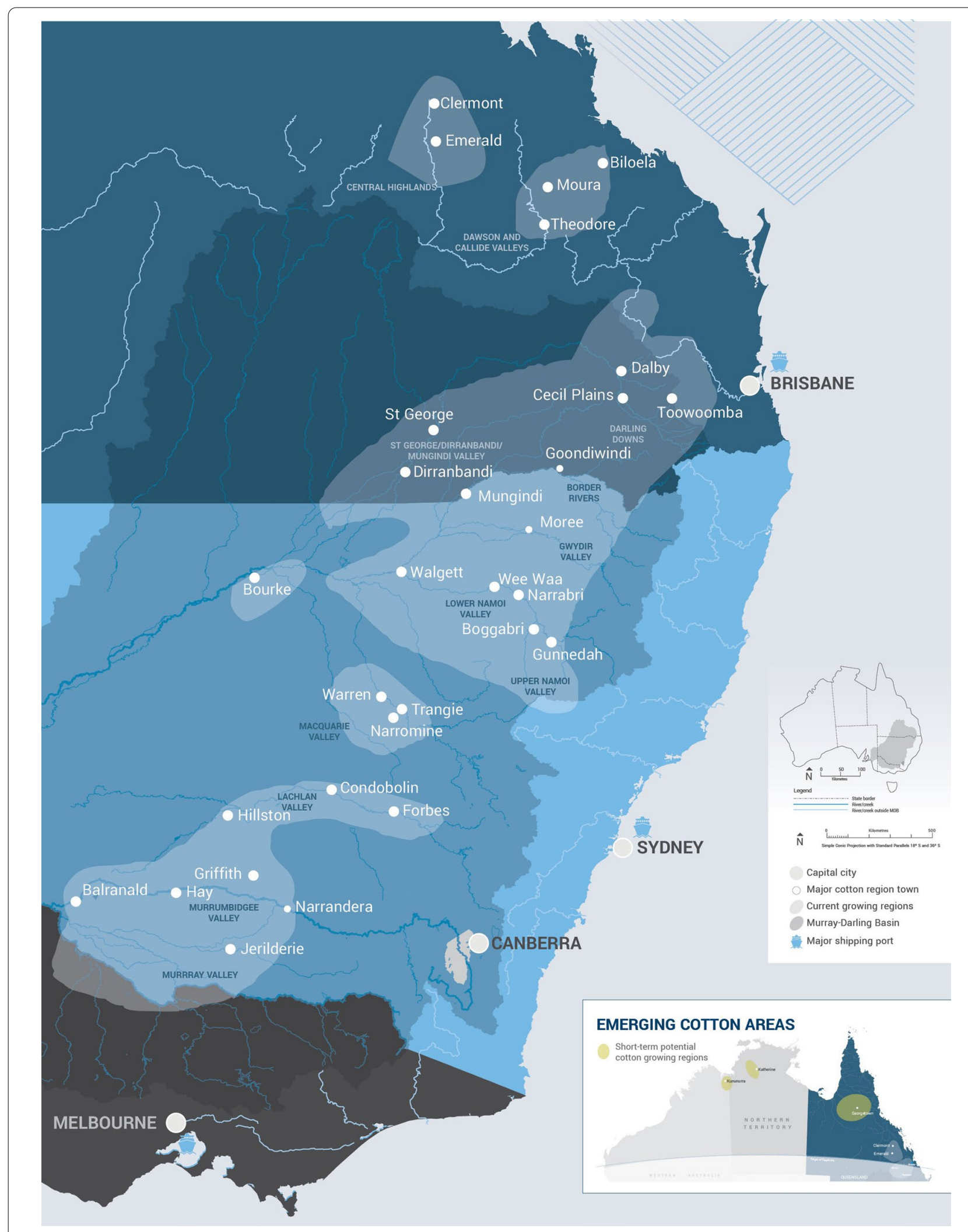

Fig. 1 Australian cotton growing regions and emerging areas ( Source: Cotton Australia 2021) 


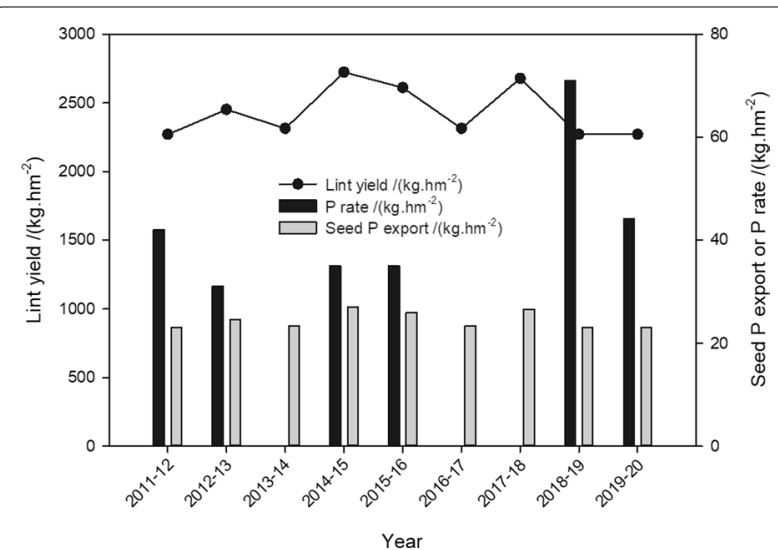

Fig. 2 Average lint yield (Cotton Year Book, 2011 to 2020), P fertiliser use (CRDC-Annual cotton grower surveys, 2011-2012 to 2019-2020) and seed $\mathrm{P}$ export estimates

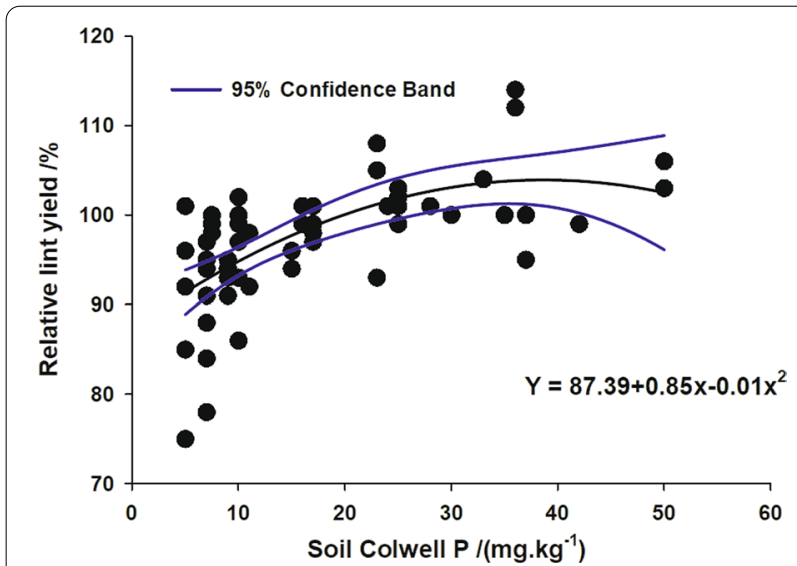

Fig. 3 Cotton lint yield response to fertiliser $\mathrm{P}$ as a function of soil Colwell P ( adapted from Hulme (2015))

25 30 cm depths (Singh et al. 2005), while Duggan et al. (2007) suggested cotton plants required P applications of $60 \mathrm{~kg} \cdot \mathrm{hm}^{-2}$ and $80 \mathrm{~kg} \cdot \mathrm{hm}^{-2}$ over one or two seasons in the Ord River region of Western Australia.

Given the more recent understanding of the importance of soil $\mathrm{P}$ reserves in deeper profile layers (Bell et al. 2012), and the possible role of other soil P pools that can buffer the more readily available Colwell $\mathrm{P}$ (Wang et al. 2007), it is unfortunate that deeper and more intensive soil analyses were not undertaken for these extensive study sites. However, after accepting those limitations these studies suggest that either (i) cotton is very efficient at extracting P from soil with low available P concentrations, possibly due to the strong mycorrhizal associations formed in cotton root systems (Bell et al. 2006; Eskandari et al. 2017a, 2017b), and/or (ii) cotton is relatively ineffective at responding to patches of elevated $\mathrm{P}$ availability such as when high rates of $\mathrm{P}$ are applied in bands or cultivated soil layers, possibly due to poor root proliferation responses. A glasshouse investigation by McLaren et al. (2013) provided possible examples of both characteristics. In that study, unfertilised cotton plants were able to accumulate approximately twice the amount of $\mathrm{P}$ as faba bean plants growing for the same growth duration in the same low $\mathrm{P}$ soils (Colwell $\mathrm{P}$ of $2.0 \sim 8.0 \mathrm{mg} \cdot \mathrm{kg}^{-1}$ ). However, when P fertiliser was applied in a variety of ways (dispersed through the soil volume, banded or mixed through defined soil layers), faba beans responded by at least doubling plant $\mathrm{P}$ uptake (particularly where $P$ was concentrated in bands or enriched in certain soil layers), while cotton increased $\mathrm{P}$ uptake by only $30 \%-40 \%$ with no apparent preference for any application strategy. This limited response to applied P fertiliser was also reported in a subsequent investigation by Bell (2014), which was unable to derive a critical Colwell $\mathrm{P}$ concentration due to inconsistent responses to applied $P$ fertiliser in field studies in southern Queensland. They concluded that the uptake of $\mathrm{P}$ from concentrated bands by cotton roots was inefficient/poor and that dispersing $\mathrm{P}$ fertiliser through the plant beds was likely to provide the best opportunity for plants to acquire P. The dispersion of $\mathrm{P}$ fertiliser throughout the cotton beds requires thorough mixing to provide maximum opportunity for cotton roots to acquire $\mathrm{P}$, with observations from field studies suggesting that broadcasting and then incorporating $\mathrm{P}$ using tillage during bed formation did not provide well dispersed P through the bed/hill (Bell 2014). This suggests that effective dispersal of applied $P$ fertiliser will require intensive tillage operations, which conflicts with best practice for sustainable cotton cropping systems that aim for minimum tillage and permanent beds (Hulugalle et al. 2020). Soil biological health benefits such as mycorrhizal networks in reduced tillage systems are aspects of soil health that will impact crop P acquisition. Mycorrhizal colonisations are reported to be initiated in surface soil and colonise the roots downwards (Nehl et al. 1999), but the influence of cropping systems or tillage on mycorrhizal colonisation in cotton has not been reported yet (Hulugalle et al. 2004).

An investigation by Bell (2014) and Griffith and Guppy (2016) on a long-term rainfed experiment managed by Incitec Pivot Fertilisers Ltd suggested that the critical Colwell P concentrations for P response could be as high as $25.0 \mathrm{mg} \cdot \mathrm{kg}^{-1}$-significantly higher than the $6.0 \mathrm{mg} \cdot \mathrm{kg}^{-1}$ of P previously reported by Dorahy et al. (2004). This experimental site was characterised by a wide range of Colwell $\mathrm{P}$ concentrations in the top $10 \mathrm{~cm}$ of the soil profile ( 6.0 to $64.3 \mathrm{mg} \cdot \mathrm{kg}^{-1}$ ), with subsoil Colwell $\mathrm{P}$ typically $<5.0 \mathrm{mg} \cdot \mathrm{kg}^{-1}$ in all fertiliser histories 
(annual applications of 0,10 and $20 \mathrm{~kg} \cdot \mathrm{hm}^{-2}$ of P). The cotton crop had limited access to the P-enriched topsoil layer (few surface roots and occasional drying of topsoil layers between rain events), which may have contributed to the higher critical Colwell P value derived in this study. Interestingly, despite the strong yield response to increasing available $\mathrm{P}$, the cotton crop was not able to respond to $\mathrm{P}$ fertiliser bands applied in the low-P subsoils (i.e. bands at $20 \mathrm{~cm}$ depth), even when the crops were otherwise under severe $\mathrm{P}$ deficiency. The authors suggested that the long-term enrichment of soil with regular P fertiliser additions would likely provide the most stable $\mathrm{P}$ supply to the plant, rather than attempting to obtain an immediate response in the season of $\mathrm{P}$ application-the concept of "feed the soil to feed the plant".

Other soil properties may also influence cotton $\mathrm{P}$ responsiveness. Rochester (2010) conducted a P response experiment in paired sodic (Colwell $\mathrm{P}$ of $6.4 \mathrm{mg} \cdot \mathrm{kg}^{-1}$ and Exchangeable sodium percentage (ESP) of 9.3\%) and non-sodic (Colwell P of $13.3 \mathrm{mg} \cdot \mathrm{kg}^{-1}$ and ESP of $4.2 \%$ ) sites and reported a lint yield response at the non-sodic site, despite Colwell P concentrations being well above the previously derived values of Dorahy et al. (2004). The lack of $\mathrm{P}$ responses at the sodic site, despite lower Colwell $\mathrm{P}$ concentrations, suggests that soil sodicity may also limit cotton growth (Dodd et al. 2013) and potentially impede crop P responses. Soil amelioration to minimise the sodicity also needs to be considered to improve the $\mathrm{P}$ fertiliser efficiency in those sodic soils. The P responses observed in recent trials, where Colwell $\mathrm{P}$ concentrations were greater than $6.0 \mathrm{mg} \cdot \mathrm{kg}^{-1}$ (Schwenke et al. 2021), indicate that critical Colwell P concentrations in the cotton-growing soils of northern NSW are not fixed and are reliant on other soil and crop factors.

While yield responses were observed in Macquarie Valley soils when Colwell P concentrations were below a critical Colwell P concentration of $10.0 \mathrm{mg} \cdot \mathrm{kg}^{-1}$ (Hulme 2015), the sporadic crop responses to $P$ fertiliser in other regions indicate that a single soil Colwell $\mathrm{P}$ critical value may not fit all cotton-growing soils. The current expansion of the cotton growing regions to the northern Territory, northern Qld, northwest Western Australia and southern NSW (Fig. 1), where the soil types are often different to Vertisols, further emphasises the need for regional or site-specific P management. Future research on improving $\mathrm{P}$ nutrition in cotton requires detailed mechanistic studies of the cotton plant and root responses in soils typical of each cotton-growing region under a variety of management approaches, including crop rotation, irrigation and soil management practices. Such research should incorporate a cropping systemlevel approach to study the interaction of soil physics, chemistry and biology on P uptake by the cotton crop.
In particular, the recent new knowledge of mycorrhizal colonisation in sodic and non-sodic soils (Eskandari et al. 2017b) determined under controlled environment conditions needs to be explored under field conditions to improve the understanding of the interaction between mycorrhiza and cotton plant response to applied $\mathrm{P}$.

\section{Cotton crop $\mathrm{P}$ accumulation and seed $\mathrm{P}$ export}

$\mathrm{P}$ is removed from the field mainly in harvested cotton seeds, with very little found in the lint (Bell 2014). Rochester (2007) reported that exported cotton seed represented $69 \%$ and $60 \%$ of total plant $\mathrm{P}$ uptake for lint yields of $1798 \mathrm{~kg} \cdot \mathrm{hm}^{-2}$ and $2400 \mathrm{~kg} \cdot \mathrm{hm}^{-2}$, respectively. Seed $\mathrm{P}$ export is reported to range from $14 \mathrm{~kg} \cdot \mathrm{hm}^{-2}$ for a cotton crop with lint yield of $975 \mathrm{~kg} \cdot \mathrm{hm}^{-2}$ to $28 \mathrm{~kg} \cdot \mathrm{hm}^{-2}$ for a cotton crop yielding $2725 \mathrm{~kg} \cdot \mathrm{hm}^{-2}$ (Rochester 2007). The P export values derived from Rochester (2007) were likely higher than the industry average due to the high soil $\mathrm{P}$ status at the experimental sites. The differences in seed $\mathrm{P}$ concentration between experiments in southern Queensland $(0.40 \% \sim 0.65 \%)$ and those in northwest NSW $(0.56 \% \sim 0.84 \%)$ further emphasise that industry-average $\mathrm{P}$ removal is likely lower than the values suggested by Rochester (2007). A cotton crop with a lint yield of $2724 \mathrm{~kg} \cdot \mathrm{hm}^{-2}$ would remove $28 \mathrm{~kg} \cdot \mathrm{hm}^{-2}$ $\mathrm{P}$ at harvest based on results reported in Rochester (2007) and $24 \mathrm{~kg} \cdot \mathrm{hm}^{-2} \mathrm{P}$ (with P removal of $2.5 \mathrm{~kg}$ per tonne of raw cotton and $45 \%$ lint turnout) based on Bell (2014). Regardless, crops that yield $2724-3178 \mathrm{~kg} \cdot \mathrm{hm}^{-2}$ will need to accumulate $40-60 \mathrm{~kg} \cdot \mathrm{hm}^{-2} \mathrm{P}$ (Rochester and Constable 2015). Constable and Bange (2015) suggested that to achieve a theoretical maximum lint yield of $5000 \mathrm{~kg} \cdot \mathrm{hm}^{-2}$, the cotton crop would need to take up P of $83 \mathrm{~kg} \cdot \mathrm{hm}^{-2}-$ a challenging proposition for soils with declining indigenous $\mathrm{P}$ availability throughout the soil profile. To consistently achieve cotton yields of $3632 \sim 4313 \mathrm{~kg} \cdot \mathrm{hm}^{-2}$ growers will face a challenge to optimise soil and irrigation management and its interaction with relative immobile nutrients such as P. Further research is required to develop strategies to address these challenges.

\section{Soil and crop management factors that could influence $P$ acquisition and crop response}

Bell (2014) concluded that future research needs to focus on the crop root responses to the method and placement of $\mathrm{P}$ fertiliser, and on the interaction between these factors and soil moisture dynamics in the P-enriched soil layers. Poor responses to applied P in the past have been attributed to decreased soil moisture in the topsoil layers under rainfed conditions (Hibberd et al. 1990; Singh et al. 2005; Wang et al. 2010). Irrigated cotton systems have the potential to maintain 
optimum soil moisture conditions for crop P uptake, but irrigation systems and practices vary widely across the cotton industry. In Australian cotton farming systems, there are currently a range of soil and irrigation management practices that may have implications for cotton root responses including: (1) Skip-furrow irrigation with $1 \mathrm{~m}$ bed spacings, where every alternate furrow is irrigated for an extended period of time to saturate the soil profile; (2) Furrow irrigation with $1 \mathrm{~m}$ bed spacings, where every single furrow is irrigated; (3) Furrow irrigation with $1.5 \mathrm{~m}$ bed spacings, where every single furrow is irrigated; (4) $2 \mathrm{~m}$ beds, where every single furrow is irrigated; (5) Bankless channel irrigation, where the entire field is saturated before water is drained into the next bay and (6) Lateral and pivot overhead irrigation, where irrigation is applied more frequently but in smaller amounts. Cotton growers using furrow irrigation systems utilise a range of deficit triggers to manage the frequency of irrigation events. All these types of irrigation, in conjunction with incrop rainfall, have different effects on the wetting and drying cycles of the soil which in turn will have implications for root growth and nutrient uptake. These wetting and drying cycles may also interact with other nutrients such as nitrogen to alter plant growth and $\mathrm{P}$ response. The ability of the cotton plant to utilise soil and applied $\mathrm{P}$ is further complicated by stratification of available $\mathrm{P}$ within the soil profile caused by long periods of continuous cropping, which will increasingly lead to a mismatch between the profile distributions of available $P$ and where cotton roots are actively acquiring water and nutrients.

To date, researchers of the long-term irrigated cotton cropping systems in Australia (Rochester 2007, 2011; Hulugalle and Scott 2008; Hulugalle et al. 2010) have not investigated cotton responses to $\mathrm{P}$ application under various cropping, tillage or irrigation systems. Adequate to high soil Colwell $\mathrm{P}$ concentrations at the Australian Cotton Research Institute long-term sites is a likely reason for the lack of attention to $P$ fertiliser requirements earlier. Although the Colwell P levels of these sites have declined somewhat (Schwenke et al. 2021), these soils are still characterised by higher $P$ availability than many newer regions growing cotton in Australia. Research is needed to find the most effective time and method for P application within a cotton cropping system. The lack of strong responses to $\mathrm{P}$ applied directly before or at cotton planting, especially when banded, suggests that $\mathrm{P}$ may be more effective if applied to other crops in the cotton rotation. A good example is the glasshouse study by McLaren et al. (2013), which showed that the most effective $\mathrm{P}$ utilisation by cotton was obtained by applying $\mathrm{P}$ prior to sowing faba bean in a cotton-faba bean rotation.

\section{Role of manures and organic wastes on $\mathrm{P}$ response}

Organic amendments such as livestock manure, poultry manure, biosolids and cotton gin trash are generated in abundance in Australia. The benefits to soil health (Ghosh et al. 2008) and potential off-farm impacts (Nachimuthu et al. 2021) of these amendments have been researched. Recently, the expansion of the cotton industry in southern NSW has resulted in greater exploration of the benefits of locally available poultry manure (Quayle 2018) for cotton production. Previous studies on cotton-growing Vertisols suggested few short-term benefits to soil quality from the application of organic amendments (Ghosh et al. 2008). A recent investigation in southern NSW identified significant variability in nutrient concentrations, including $\mathrm{P}$, between different batches of chicken manure (Quayle 2018). While this variability provides a challenge for nutrient budgeting for the cotton crop, Quayle (2018) reported the benefits to soil P either through the conversion of organic P to inorganic $\mathrm{P}$ from manure or from the release of $\mathrm{P}$ from other inorganic sources during the growing season. Future research should focus on the benefits of incorporating these locally available organic amendments (both in topsoil and subsoil) in altering soil $P$ pools over the short and longer term, its interaction with improvements in soil physical properties, and ultimately crop P nutrition.

\section{Conclusion and future research gaps}

This review focussed on results from Australian P fertiliser response trials. Enrichment of depletion or inherently low-P topsoil layers over the long term has provided yield benefits and reinforced the notion of feeding the soil (i.e. enhancing soil $\mathrm{P}$ fertility) to feed the plant. Future work needs to determine the responses of cotton to increasingly stratified soil $\mathrm{P}$ profiles and subsoil $\mathrm{P}$ depletion, especially in soils that have little movement of $\mathrm{P}$ down the profile. The cotton yield responses to $\mathrm{P}$ fertiliser in the Macquarie Valley and sporadic responses in northwest NSW and central and southern Queensland suggest critical Colwell P concentrations may be needed for each cotton-growing region and soil type. Evidence of P stratification in soil profiles may mean critical P levels for subsoils also need to be considered alongside those for topsoils. However, for these studies to be undertaken efficiently, studies to improve the mechanistic understanding of interactions between fertiliser $\mathrm{P}$ applications and cotton roots are urgently required before large scale field programs are conducted. It seems clear that factors such as fertiliser placement, timing and possibly $\mathrm{P}$ product may be just as important, if not more so, than $\mathrm{P}$ rate in ensuring cotton crops are able to acquire 
sufficient $\mathrm{P}$ to achieve high potential yields. Once these fundamentals of cotton root-P fertiliser interactions are better understood, future research should then focus on (1) studying the interaction of crop rotation, soil management and $\mathrm{P}$ application timing on cotton $\mathrm{P}$ responses, to improve the cropping system productivity; (2) studying the interaction of wetting and drying cycles and nitrogen supply on cotton P response; (3) comparing annual P applications with larger applications every 3-5 years in terms of $\mathrm{P}$ use efficiency and overall farming system sustainability and soil health; and (4) investigating the effects of manure or compost applications on soil $\mathrm{P}$ dynamics and fertiliser $\mathrm{P}$ requirements of cotton grown on soils with physical constraints.

\section{Acknowledgements}

The authors gratefully acknowledge Simon Clarendon and John Friend of NSW DPI who provided critical feedback on the manuscript. The authors also acknowledge the assistance from Amanda Thomas who provided the trial report on phosphorus in Macquarie valley.

\section{Authors' contributions}

Nachimuthu $\mathrm{G}$ and Schwenke $\mathrm{G}$ designed the paper's scope and contributed to the writing. Nachimuthu $\mathrm{G}$ led the writing and data synthesis. Bell $\mathrm{M}$ and Hulme $\mathrm{P}$ contributed towards results and discussion. Mercer $\mathrm{C}$ and Bischof $\mathrm{C}$ were involved in collection of literatures. All authors approved the final manuscript.

\section{Funding}

This work was supported by funding from the Australian Government Department of Agriculture, Water and the Environment as a part of its Rural R\&D for Profit program and the Cotton Research and Development Corporation through the "More profit from nitrogen: enhancing the nutrient use efficiency of intensive cropping and pasture systems" project.

\section{Availability of data and materials}

All data used in this paper were from previously published reports and research papers.

\section{Declarations}

Ethics approval and consent to participate

Not applicable.

\section{Consent for publication \\ Not applicable.}

\section{Competing interests}

The authors declare that they have no competing interests.

\section{Author details}

${ }^{1}$ New South Wales Department of Primary Industries, Australian Cotton Research Institute, Narrabri, NSW 2390, Australia. ${ }^{2}$ New South Wales Department of Primary Industries, Tamworth Agricultural Institute, Calala, NSW 2340, Australia. ${ }^{3}$ The School of Agriculture and Food Sciences, The University of Queensland, Gatton, QLD 4343, Australia. ${ }^{4}$ Sustainable Soil Management, Warren, NSW 2824, Australia.

Received: 1 November 2021 Accepted: 27 January 2022

Published online: 21 February 2022

\section{References}

Bell M, Seymour N, Stirling GR, et al. Impacts of management on soil biota in Vertosols supporting the broadacre grains industry in northern Australia. Soil Res. 2006;44:433-51. https://doi.org/10.1071/SR05137.

Bell M, Lester D, Smith L, et al. Increasing complexity in nutrient management on clay soils in the northern grain belt-nutrient stratification and multiple nutrient limitations. In: 16th Australian agronomy conference, Armidale. 2012. http://www.regional.org.au/au/asa/2012/nutrition/8045_ bellm.htm. Accessed 18 Oct 2021

Bell M, Lester D, Sands D. Nutritional strategies to support productive farming systems. Grains Research and Development Corporation. GRDC update paper. 2020. https://grdc.com.au/resources-and-publications/ grdc-update-papers/tab-content/grdc-update-papers/2020/02/nutri tional-strategies-to-support-productive-farming-systems. Accessed 20 Oct 2021.

Bell M. Developing soil testing and fertiliser response guidelines to manage $P_{\text {, }}$ $\mathrm{K}$ and $\mathrm{S}$ fertility for irrigated and dryland cotton cropping systems. Final Report. Cotton Research and Development Corporation and The University of Queensland. 2014. http://www.insidecotton.com/xmlui/handle/1/ 4579. Accessed 20 Oct 2021.

Colwell JD. The estimation of phosphorus fertilizer requirements of wheat in southern New South Wales by soil analysis. Aust J Exp Agric. 1963;3:1907. https://doi.org/10.1071/EA9630190.

Constable GA, Bange MP. The yield potential of cotton (Gossypium hirsutum L.). Field Crops Res. 2015;182:98-106. https://doi.org/10.1016/j.fcr.2015. 07.017.

Cotton Australia. "Australian Cotton Statistics". Mascot, NSW, Australia: Cotton Australia; 2021. https://cottonaustralia.com.au/statistics. Accessed 30 Sept 2021.

CRDC. 2020 Cotton Grower Survey. Narrabri, Australia: Cotton Research and Development Corporation; 2020. http://www.insidecotton.com/xmlui/ handle/1/4827. Accessed 10 Oct 2021.

Dodd K, Guppy CN, Lockwood PV, et al. The effect of sodicity on cotton: does soil chemistry or soil physical condition have the greater role? Crop Pasture Sci. 2013;64:806-15. https://doi.org/10.1071/CP13078.

Dorahy CG, Rochester IJ, Blair GJ. Response of field-grown cotton (Gossypium hirsutum L.) to phosphorus fertilisation on alkaline soils in eastern Australia. Soil Res. 2004;42:913-20. https://doi.org/10.1071/SR04037.

Duggan BL, Yeates SJ, Gaff N, et al. Phosphorus fertilizer requirements and nutrient uptake of irrigated dry-season cotton grown on virgin soil in tropical Australia. Commun Soil Sci Plan. 2007;39:282-301. https://doi. org/10.1080/00103620902896761.

Eskandari S, Guppy CN, Knox OGG, et al. Mycorrhizal symbioses of cotton grown on sodic soils: a review from an Australian perspective. Pedosphere. 2017a;27:1015-26. https://doi.org/10.1016/S1002-0160(17) 60491-0.

Eskandari S, Guppy CN, Knox OGG, et al. Mycorrhizal contribution to phosphorus nutrition of cotton in low and highly sodic soils using dual isotope labelling ( ${ }^{32} \mathrm{P}$ and $\left.{ }^{33} \mathrm{P}\right)$. Soil Biol Biochem. 2017b;105:37-44. https://doi. org/10.1016/j.soilbio.2016.11.004.

Ghosh S, Hulugalle N, Lockwood P, et al. Organic amendments influence nutrient availability and cotton productivity in irrigated Vertosols. Aust J Agric Res. 2008:59:1068-74. https://doi.org/10.1071/AR08141.

Griffith B, Guppy C. Phosphorus availability in raingrown cotton. Final Report 2015. Narrabri, NSW: Cotton Research and Development Corporation; 2016. p. 14. http://www.insidecotton.com/xmlui/handle/1/4508. Accessed 12 Oct 2021.

Hibberd D, Ladewig J, Hunter M, et al. Responses in cotton yields to nitrogen and phosphorus fertilisers in the Emerald Irrigation Area, central Queensland. Aust J Exp Agric. 1990;30:661-7. https://doi.org/10.1071/EA9900661.

Hulme P. Macquarie field trials, industry research and on-farm trends and managmement of phosphorus, potassium and zinc. In: Anon, editor. Macquarie valley cotton field trials 2014/15. Cottoninfo; 2015. p. 9-21. https://www.cottoninfo.com.au/sites/default/files/img/Booklet_2015.pdf. Accessed 10 Oct 2021.

Hulugalle NR, Scott F. A review of the changes in soil quality and profitability accomplished by sowing rotation crops after cotton in Australian Vertosols from 1970 to 2006. Soil Res. 2008:46:173-90. https://doi.org/10. 1071/SR07077. 
Hulugalle NR, NehI DB, Weaver TB. Soil properties, and cotton growth, yield and fibre quality in three cotton-based cropping systems. Soil Till Res. 2004;75:131-41. https://doi.org/10.1016/j.still.2003.07.003.

Hulugalle NR, Weaver TB, Finlay LA. Soil water storage and drainage under cotton-based cropping systems in a furrow-irrigated Vertisol. Agr Water Manage. 2010;97:1703-10. https://doi.org/10.1016/j.agwat.2010.06.001.

Hulugalle NR, Nachimuthu G, Kirkby K, et al. Sowing maize as a rotation crop in irrigated cotton cropping systems in a Vertosol: effects on soil properties, greenhouse gas emissions, black root rot incidence, cotton lint yield and fibre quality. Soil Res. 2020;58:137-50. https://doi.org/10.1071/SR19242.

Isbell RF. National committee on soil and terrain. The Australian soil classification. 3rd ed. Melbourne: CSIRO Publishing; 2021.

McLaren TI, Bell MJ, Rochester IJ, et al. Growth and phosphorus uptake of faba bean and cotton are related to Colwell-P concentrations in the subsoil of Vertosols. Crop Pasture Sci. 2013;64:825-33. https://doi.org/10.1071/ CP13025.

Nachimuthu G, Hulugalle NR, Watkins MD, et al. Soil nitrogen and carbon changes in a biosolid amended sodic vertisol with a history of treated sewage effluent-enriched water irrigation. Soil Use Manage. 2021. https://doi.org/10.1111/sum.12748 (accepted).

Nehl DB, McGee PA, Torrisi V, et al. Patterns of arbuscular mycorrhiza down the profile of a heavy textured soil do not reflect associated colonization potential. New Phytol. 1999;142:495-503. https://doi.org/10.1046/j.14698137.1999.00407.x.

Quayle W. Optimising the management of manure in southern cotton. Final Report. Cotton Research and Development Corporation and Deakin University. 2018. http://www.insidecotton.com/xmlui/handle/1/4670. Accessed 12 Oct 2021.

Rochester IJ. Nutrient uptake and export from an Australian cotton field. Nutr Cycl Agroecosys. 2007;77:213-23. https://doi.org/10.1007/ s10705-006-9058-2.

Rochester IJ. Phosphorus and potassium nutrition of cotton: interaction with sodium. Crop Pasture Sci. 2010;61:825-34. https://doi.org/10.1071/CP100 43.

Rochester IJ. Sequestering carbon in minimum-tilled clay soils used for irrigated cotton and grain production. Soil Till Res. 2011;112:1-7. https://doi. org/10.1016/j.still.2010.10.012.

Rochester IJ, Constable GA. Improvements in nutrient uptake and nutrient use-efficiency in cotton cultivars released between 1973 and 2006. Field Crops Res. 2015;173:14-21. https://doi.org/10.1016/j.fcr.2015.01.001.

Schwenke G, Nachimuthu G, Baird J, et al. More profit from nitrogen: enhancing nutrient use in cotton. Final report submitted to Cotton Research and Development Corporation and Australian Federal Department of Agriculture, Water and the Environment. NSW Department of Primary Industries, CSIRO, University of Melbourne, University of Queensland, UNE. 2021. https://www.crdc.com.au/sites/default/files/Final\%20Report More\%20Profit\%20from\%20Nitrogen_NSW\%20Cotton_V3.pdf. Accessed 30 Sept 2021.

Singh DK, Sale PWG, Routley RR. Increasing phosphorus supply in subsurface soil in northern Australia: rationale for deep placement and the effects with various crops. Plant Soil. 2005;269:35-44. https://doi.org/10.1007/ s11104-004-2475-6.

Wang X, Lester DW, Guppy CN, et al. Changes in phosphorus fractions at various soil depths following long-term $P$ fertiliser application on a Black Vertosol from south-eastern Queensland. Soil Res. 2007;45:524-32. https://doi.org/10.1071/SR07069.

Wang X, Tang C, Guppy CN, et al. Phosphorus acquisition characteristics of cotton (Gossypium hirsutum L.) plant: a review. In: 19th world congress of soil science, soil solutions for a changing world, 1-6 Aug 2010, Brisbane, Australia, p. 88-91. 2010. https://www.iuss.org/19th\%20WCSS/Sympo sium/pdf/1942.pdf. Accessed 29 Sept 2021.

Ready to submit your research? Choose BMC and benefit from:

- fast, convenient online submission

- thorough peer review by experienced researchers in your field

- rapid publication on acceptance

- support for research data, including large and complex data types

- gold Open Access which fosters wider collaboration and increased citations

- maximum visibility for your research: over 100M website views per year

At BMC, research is always in progress.

Learn more biomedcentral.com/submissions 